\title{
Analisis Pendapatan dan Keuntungan Relatif Usahatani Jagung di Desa Bitefa Kecamatan Miomaffo Timur Kabupaten TTU
}

Simon Juan Kune ${ }^{\mathrm{a}}$

${ }^{a}$ Fakultas Pertanian, Universitas Timor, Kefamenanu, TTU - NTT, Indonesia.

\section{Article Info}

\section{Article history:}

Received 18 Februari 2017

Received in revised form 20 Maret 2017

Accepted 31 Maret 2017

Keywords:

Analisis Pendapatan

Keuntungan Relatif

Usahatani Jagung

\section{Pendahuluan}

Salah satu komoditas tanaman pangan musiman yang sudah diusahakan oleh masyarakat petani secara turun temurun Jagung (Zea mays L). Tanaman in berfungsi ganda baik untuk dikonsumsi sebagai sayuran dan juga pengganti pangan untuk beras, di samping bahan baku industri pakan ternak serta industri pangan olahan lainya dengan berbagai merek. komoditas jagung juga mempunyai gizi yang baik bagi kesehatan manusia

Salah satu Desa/kelurahan yang mewakili Kecamatan Miomaffo Timu dalam penelitian ini adalah Desa Bitefa. Kecamatan Miomaffo Timur memilik jumlah luas panen dan jumlah produksi tertinggi, dengan jumlah produks jagung selama lima (5) tahun terakhir sangat berfluktuasi yakni mengalami peningkatan dari tahun 2008 hingga 2010 kemudian mengalami penurunan di tahun 2011 dan meningkat lagi pada tahun 2012 (BPS TTU, 2013)

Desa ini dipilih karena memiliki luas lahan dan produksi jagung tertingg dari seluruh Desa/Kelurahan di Kecamatan Miomaffo Timur, dengan luas panen 353 ha dan produksi sebesar $999.343 \mathrm{~kg}$ dengan demikian maka produktivitas yang diperoleh adalah 2.831 ton/ha (BPS TTU 2013). Berdasarkan data tersebu terlihat ada kesenjangan antara luas panen dan produksi yang diperoleh, yakn dari lahan seluas 353 ha berdasarkan produksi jagung potensial dimana $1 \mathrm{ha}$ dapat menghasilkan 4 hingga 6 ton maka produksi seharusnya adalah minima $1.412 .000 \mathrm{~kg}$.

Umumnya masyarakat di Desa Bitefa berprofesi sebagai petani, Sebagai pangan pokok bagi masyarakat maka tanaman jagung telah lama dan secara turun temurun sudah diusahakan oleh masyarakat. Berdasarkan data survei awa ini tentu ada kesenjangan antara produksi yang ada dengan pendapatan dan keuntungan yang diterima oleh petani. Hasil dari usahatani jagung yang diterima biasanya digunakan untuk memenuhi kebutuhan hidup masyarakat. Berdasarkan hal tersebut, penelitian ini diarahkan memperoleh gambaran serta mengetahui pendapatan dan keuntungan relatif dari usahatani jagung di desa Bitefa.

\section{Metode}

Penelitian ini dilakukan bulan Desember hingga April 2014. Data yang digunakan dalam penelitian ini adalah data primer yang diperoleh dengan teknik wawancara langsung dengan responden atau petani di lokasi penelitian berdasarkan daftar pertanyaan yang disiapkan oleh peneliti sedangkan data sekunder diperoleh dari instansi atau lembaga terkait. Penentuan sampe menggunakan rumus Slovin (Kuncoro, 2001) sehingga diperoleh 46 responden. Data yang diperoleh dikumpulkan kemudian ditabulasi dan dianalisis berdasarkan tujuan penelitian: Untuk menjawab tujuan pertama yaitu mengetahui gambaran umum usahatani jagung peneliti menggunakan metode analisis deskriptif kualitatif (Nazir, 1988). Untuk menjawab tujuan kedua, dilakukan dengan menggunakan analisis pendapatan yaitu selisih antara total penerimaan dan total biaya (Soekartawi, 1995) yang secara skematis dapat dirumuskan dengan Pd $=$ TR-TC. Untuk menjawab tujuan ketiga Keuntungan relatif yang diperoleh dari usahatani jagung menggunakan analisis R/C Rasio. Keuntungan Relatif dikenal sebagai pembanding (nisbah) antara penerimaan dengan biaya rumus yang digunakan adalah $\mathrm{a}=\mathrm{R} / \mathrm{C}$, dimana $\mathrm{R}$ (revenue) atau Penerimaan dan C (cost) atau Pengeluaran/Biaya Soekartawi (1983). Adapun Kriteria yang digunakan untuk mengetahui keuntungan relatif suatu kegiatan usaha menurut Soekartawi (1983) adalah:

$\mathrm{R} / \mathrm{C}$ Rasio $>1$ kegiatan usaha menguntungkan secara ekonomis.

$\mathrm{R} / \mathrm{C}$ Rasio = 1 kegiatan usaha mencapai titik impas

R/C Rasio <1 berarti kegiatan usaha tidak menguntungkan secara ekonomis

\section{Hasil dan Pembahasan}

\subsection{Gambaran Usahatani Jagung}

Jagung yang digunakan dalam usahatani di desa Bitefa adalah jagung loka yang telah dipersiapkan oleh petani dari hasil panen kali lalu (tahun sebelumnya) Tahapan usahatani jagung yang dilakukan petani di lokasi penelitian meliputi: pengolahan lahan, penanaman, pemeliharaan, panen dan pasca panen

\subsection{Analisis Pendapatan Usahatani Jagung}

Perhitungan pendapatan dalam penelitian ini adalah selisih antara total penerimaan dengan total biaya yang mana total biaya diperoleh dari total biaya variabel dan total biaya tetap. Penjabaran pendapatan usahatani jagung sebagai berikut:

a. Biaya Usahatani Jagung

Biaya usahatani jagung yang dimaksudkan dalam penelitian ini meliputi biaya variabel atau biaya tidak tetap dan biaya tetap berdasarkan hasil penelitian total biaya usahatani jagung di Desa Bitefa pada 46 responden sebesar Rp 24.123.000,- dengan rata-rata biaya sebesar Rp 524.413,- dan uraiannya sebagai berikut.

\section{b. Biaya Variabe}

Biaya variabel (variable cost) merupakan biaya yang dikeluarkan untuk pembayaran input-input variabel dalam proses produksi jangka pendek. Biaya variabel dalam penelitian ini terdiri dari biaya konsumsi dan biaya transportasi, hal ini karena untuk tenaga kerja hingga saat ini petani masih menggunakan tenaga kerja dalam keluarga, serta biaya transportasi hanya diperuntukkan bag pengangkutan pupuk kandang dan pengangkutan hasil panen. Jelasnya dapat diperhatikan pada Tabel 1

Tabel 1. Rincian Biaya Variabel Usahatani Jagung di Desa Bitefa

\begin{tabular}{clrr}
\hline No & Jenis Biaya Variabel & Rata-rata Biaya (Rp) & \multicolumn{1}{c}{ Total Biaya (Rp) } \\
\hline 1 & Konsumsi & 262.206 .50 & 12.061 .500 \\
2 & $\begin{array}{l}\text { Transportasi untuk pupuk } \\
\text { kandang pengangkutan hasil }\end{array}$ & 91.202 .27 & 4.195 .304 \\
\hline
\end{tabular}

Tenaga kerja sebab tenaga kerja yang digunakan merupakan tenaga kerja dalam keluarga sehingga yang dihitung adalah biaya konsumsi dan Transportasi.

\section{c. Biaya Tetap}

Biaya tetap dalam penelitian ini merupakan biaya peralatan (ember, karung dan pajak) yang dinyatakan dalam satuan rupiah. Berdasarkan hasil penelitian diperoleh total biaya penyusutan alat dari 46 responden sebesar Rp 7.866.196 dengan rata-rata $\mathrm{Rp} 171.004,3$

Tabel 2. Rincian Biaya Tetap Usahatani Jagung

\begin{tabular}{clcc}
\hline No & \multicolumn{1}{c}{ Jenis Alat } & Rata-rata Biaya (Rp) & $\begin{array}{c}\text { Total Biaya Alat } \\
(\mathrm{Rp})\end{array}$ \\
\hline 1 & Karung & 85.502 .13 & 3.933 .098 \\
2 & Ember & 81.784 .64 & 3.762 .094 \\
3 & Pajak & 37.174 .84 & 1.710 .043 \\
\hline Total & 171.004 .3 & 7.866 .196 \\
\hline
\end{tabular}

Data Tabel 2. terlihat bahwa biaya tetap tertinggi dari usahatani jagung di desa Bitefa adalah biaya karung karena petani membutuhkan karung dalam pengangkutan jagung dan juga ember.

\section{d. Penerimaan Usahatani Jagung}

Penerimaan usahatani merupakan perkalian antara produksi dan harga jual. Satuan yang digunakan seperti satuan yang lazim digunakan antara penjual/pembeli misalnya kilogram $(\mathrm{kg})$, kuintal $(\mathrm{kw})$, ton, ikat, dan sebagainya (Soekartawi, 1995). Hasil penelitian ini harga yang ditetapkan sebesar Rp 5.000 per kilogramnya. Sehingga produksi usahatani jagung dalam 1 musim tanam dari 46 responden diperoleh sebesar $124.629 . \mathrm{kg}$ dengan rata-rata $2.790 \mathrm{~kg}$, dengan demikian penerimaan 46 responden petani usahatani jagung sebesar $\mathrm{Rp}$ 623.145.000 dengan rata-rata penerimaan responden sebesar Rp 13.546.630,43,

\section{e. Pendapatan Usahatani Jagung}

Pendapatan usahatani adalah selisih antara total penerimaan dengan semua biaya yang dikeluarkan Soekartawi (1995), Hasil perhitungan 46 responden 
petani jagung diperoleh total biaya sebesar Rp 24.123.000 dengan rata-rata total biaya Rp 524.413,- dan total penerimaan sebesar Rp 623.145.000 dan rata-rata penerimaan sebesar $13.546 .630,43$,- berdasarkan perhitungan ini diperoleh total pendapatan dari 46 responden petani jagung sebesar Rp 599.022.000,- dengan rata-rata pendapatan sebesar Rp 13.022.217,39,-

\subsection{Keuntungan Relatif (R/C Ratio) Usahatani Jagung}

Berdasarkan hasil perhitungan diperoleh total R/C Ratio dari 46 responden petani jagung sebesar 25,83 dengan rata-rata $\mathrm{R} / \mathrm{C}$ rasio sebesar 24,83 maka dapat disimpulkan bahwa usahatani jagung di Desa Bitefa berada pada posisi menguntungkan dan layak untuk diusahakan oleh petani.

\section{Simpulan}

Usahatani jagung di Desa Bitefa Kecamatan Miomaffo Timur terdiri dari kegiatan pengolahan lahan, penanaman, pemeliharaan, panen dan pasca panen. Pendapatan petani jagung sebesar Rp 623.145.000 dengan rata-rata pendapatan sebesar Rp 13.546.630,43,-. Keuntungan relatif yang diperoleh petani rata-rata $25,83>1$ dan dapat dikatakan bahwa kegiatan usahatani jagung menguntungkan secara ekonomis.

\section{Pustaka}

Kuncoro, A., 2001. Cara Menggunakan dan Memaknai Analisis Asumsi Klasik. Cetakan Pertama. Bandung: Alfabeta.

Nazir, M. 1988. Metode Penelitian, Jakarta: Chalia Indonesia.

BPS Kab. TTU. 2013. Timor Tengah Utara dalam Angka. Kefamenanu: Badan Pusat Statistik.

Soekartawi, 1983. Ilmu Usahatani dan Penelitian untuk Pengembangan Petani Kecil. Jakarta: UI Press.

Soekartawi, 1995. Analisis Usaha Tani. Jakarta: UI Press. 